\title{
Characterization of a circulating PRRSV strain by means of random PCR cloning and full genome sequencing
}

\author{
Jan Van Doorsselaere ${ }^{1 *}$, Marc Geldhof ${ }^{2}$, Hans J Nauwynck ${ }^{2}$ and Peter L Delputte 2,3
}

\begin{abstract}
PRRS is a pig disease of major economic importance that causes respiratory and reproductive problems in pigs. Over the last years it has become clear that PRRSV heterogeneity is increasing. Consequently, this has a potential impact on diagnosis and strategies to counter this disease. The use of sequence-independent PCR techniques for the detection and characterization of PRRSV could be useful to bypass problems associated with the heterogeneity of this virus.

A random PCR cloning approach was tested for the characterization of PRRSV strain 07V063 of unknown genetic background that circulated on a Belgian farm. By using this approach, 7305 bp of sequence data were obtained, distributed randomly across the genome. Using RT-PCR with strain-specific primers, the full length sequence (15014 nt) was obtained. Phylogenetic relationships using ORF5 and ORF1a (NSP2) sequences showed that 07V063 was classified in type 1 subtype 1 and that 07V063 was genetically different from prototype Lelystad Virus (LV). 07 V063 showed $87-93 \%$ aa identity with LV ORFs coding for structural proteins. Most variation (compared to LV) was noticed in Nsp2 (81\% identity) with a deletion of 28 aa. This deletion was different from other known deletions in this ORF. In conclusion, it is shown that this random PCR cloning approach can be used for the characterization of new PRRSV strains of unknown genetic background.
\end{abstract}

\section{Findings}

Porcine reproductive and respiratory syndrome (PRRS) is an economically important viral pig disease in swine producing countries worldwide. The virus can cause reproductive disorders and can give rise to respiratory problems in pigs of all ages [1]. Prevention of the disease is based on a combination of management and vaccination. Evidence is accumulating that PRRSV heterogeneity is affecting the vaccination efficiency. It is suggested that vaccines are only efficacious when the vaccine virus and the challenge virus share a sufficiently high homology [2-6]. PRRSV heterogeneity was originally considered mainly to occur between European (genotype 1) and American type (genotype 2) PRRSV, but current understanding shows a more complex situation with considerable genetic variability within genotypes [7-9]. Since such variability may affect the efficacy of

\footnotetext{
* Correspondence: jan.vandoorsselaere@katho.be

'Department of Health Care and Biotechnology, KATHO Catholic University College of South-West Flanders, Wilgenstraat 32, 8800 Roeselare, Belgium Full list of author information is available at the end of the article
}

vaccination programs and pose an obstacle for PRRSV prevention and control, knowledge on the PRRSV strains circulating on a farm may be essential for choosing an appropriate vaccine [10].

PRRSV diagnosis is mainly based on detection of PRRSV antibodies, Reverse Transcriptase (RT) PCR or virus isolation. Detection of antibodies by ELISA or IPMA is not sufficient to establish the level of PRRSV heterogeneity [11]. RT-PCR allows rapid detection and genotyping of PRRSV, but the high degree of sequence variation observed for PRRSV can influence results obtained by (real-time) RT-PCR and primers and/or probes should be carefully designed based on conserved regions $[8,12]$. The development of sequence-independent PCR techniques could be useful for the diagnosis and genotyping of unknown PRRSV isolates and for assessment of the PRRSV heterogeneity of field isolates. Several methods have been developed for the identification of viruses without prior sequence knowledge [13]. For instance, whole genome amplification and random PCR are relatively simple. In both these methods, viral

\section{Biomed Central}


particles (from biological samples or cell culture) are treated with DNAse and RNAse to remove contaminating nucleic acids. RNA and/or DNA from the viral particles is extracted and RNA is reverse transcribed to cDNA using a primer with a random 3'end. Subsequently, cDNA or viral DNA is amplified using a shorter primer (without the 3' random end). This results in DNA fragments of varying size (e.g. $0.5-2 \mathrm{~Kb}$ ) and these fragments can be cloned and sequenced. For instance Allander et al. [14] used random PCR on human respiratory tract samples which allowed identification of several unknown viruses.

The aim of this study was to test a random PCR cloning technique [14] for the detection and genotyping of a PRRSV strain of unknown genetic background.

\section{Random PCR cloning for the identification of PRRSV 07V063}

PRRSV 07V063 was isolated from an aborted foetus from a Belgian farm, by inoculation of porcine alveolar macrophages. On this farm, vaccination with Porcilis ${ }^{\mathrm{TM}}$ was in place. PRRS diagnosis was confirmed upon detection of cytopathic effect (CPE), and detection of PRRSV antigens by IPMA staining with the nucleocapsid specific mAb P3/27 [15]. The use of a random PCR approach abrogates the need for a priori sequence information and in combination with small scale shotgun sequencing, this can result in viral sequences. Virus 07V063 was grown on MARC-145 cells and concentrated as described [16] and the viral pellet was treated with DNAseI and RNAse. RNA was extracted using commercial kits and used in reverse transcription and random amplification using the tagged random hexanucleotide 5'-GCCGGAGCTCTGCAGATATCNNNNNN-3' for both first- and second strand cDNA synthesis and subsequent amplification of the cDNA with primer 5'-GCCGGAGCTCTGCAGATATC-3' [14]. Random PCR fragments ranging between 500 and 1200 bp were cloned in pCR-Blunt II-TOPO (Invitrogen). Twenty nine clones were sequenced as described [17]. Twenty three clones ( $80 \%$ of the clones) contained PRRS sequences (Table 1). The six other clones showed no match when performing BlastN http:// www.ncbi.nlm.nih.gov. The 07V063 sequences were randomly distributed across the PRRSV genome. Several clones were overlapping and six contigs (with sizes between 622 and 2072 bp) were obtained (Figure 1). Thus, without prior knowledge of the sequence it was possible to obtain 7305 bp sequence data using a random PCR cloning approach, hereby confirming PRRS identity.

\section{Full length sequence of $07 \mathrm{~V} 063$ and comparison with prototype LV}

To allow a more detailed evaluation of the PRRSV isolate 07V063, the full length genome sequence was
Table 1 Overview of the sequences from $07 \mathrm{~V} 063$ obtained by random PCR cloning

\begin{tabular}{llll}
\hline Clone & Size $(\mathbf{n t})$ & Position & \% nt identity \\
\hline 49 & 671 & $774-1444$ & 81 \\
73 & 198 & $1692-1889$ & 89 \\
104 & 826 & $1808-2633$ & 89 \\
20 & 798 & $2616-3413$ & 86 \\
105 & 375 & $3069-3443$ & 88 \\
88 & 429 & $3420-3847$ & 93 \\
33 & 332 & $3957-4288$ & 91 \\
92 & 316 & $6198-6512$ & 93 \\
61 & 713 & $6367-7079$ & 93 \\
103 & 312 & $6768-7079$ & 94 \\
35 & 364 & $6500-6863$ & 93 \\
12 & 247 & $8132-8378$ & 89 \\
51 & 627 & $8931-9557$ & 86 \\
80 & 358 & $9200-9557$ & 87 \\
82 & 622 & $11225-11846$ & 87 \\
11 & 258 & $11225-11482$ & 86 \\
81 & 601 & $11928-12528$ & 92 \\
70 & 189 & $12336-12524$ & 94 \\
40 & 277 & $12364-12640$ & 90 \\
78 & 395 & $12991-13385$ & 90 \\
57 & 935 & $13195-14129$ & 91 \\
\hline
\end{tabular}

The position of the sequences is indicated relative to LV. \% nt identity is with LV.

obtained using primers that were based on the 07V063 sequences from the random PCR cloning approach (Table 2). Overlapping amplicons (spanning the complete genome) were obtained using RT-PCR. Both strands of these fragments were directly sequenced. For the amplification of the 3'end, oligodT was used in combination with ORF7fw. A 5' end primer (5'endfw) was designed based on the alignment of genotype 1 strains LV (M96262), EuroPRRS (AY366525), SD01-08 (DQ489311), KNU-07 (FJ349261) and HKEU16 (EU076704). This primer was used in combination with primer Lavgsprev to amplify the 5'end. A full length sequence of $15014 \mathrm{nt}$ was obtained. This sequence was deposited in Genbank (Accession GU737264).

The 5' end and 3'end of 07V063 was 221 nt and 114 nt, respectively. The size of the 5'end of $07 \mathrm{~V} 063$ is identical with the 5 'end of $\mathrm{LV}$ with $92.3 \%$ identity and $17 \mathrm{nt}$

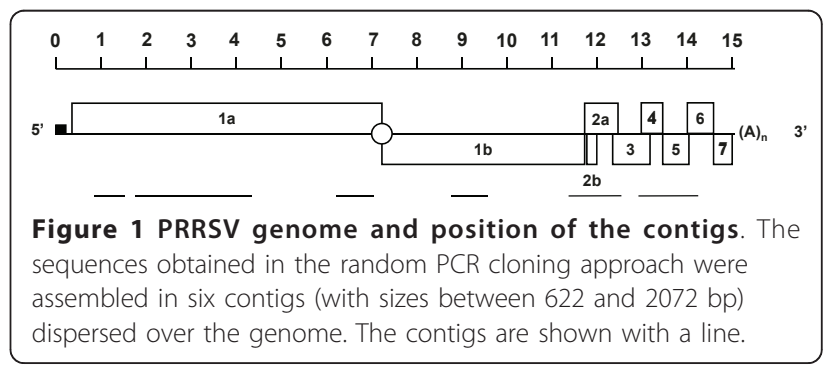


Table 2 Oligonucleotide primers used in RT-PCR amplification and nucleotide sequencing of $07 \mathrm{~V} 063$

\begin{tabular}{|c|c|c|c|c|c|}
\hline Primer & Sequence & Position & Lav92rev & caccaatgatgatgataggg & $6222-6203$ \\
\hline 5'endFW & atgatgtgtagggtattccecc & $1-22$ & Orf1-11rev & cttg caca gaca cagtttt & $6720-6702$ \\
\hline Orf1univFW & ccctttaaccatgtctggc & $111-130$ & Orf1-12rev & ttcaa ggca gttg tca ggct & $7190-7171$ \\
\hline Orf1-1fw & catcc gggtg ctgctgg ctt & 336-355 & Orf1-13rev & tca ttaa gacg acacc ggaa & $7406-7386$ \\
\hline Orf1-2fw & ggag ccaccc acgtgtt gac & $681-701$ & Orf1-14rev & cttg ccat cgga cacaa gg & 7903-7885 \\
\hline Lav49fw & aatcaatggtattcgtgctg & 1072-1091 & Orf1-15rev & tga cacc actg agcg cсga & $8396-8378$ \\
\hline Orf1-3-fw & tcaat gcctacaa ctgcccg & $1631-1650$ & Orf1-16rev & agaca cact ggtg acggggt & $8696-8676$ \\
\hline Orf1-4-fw & cttgta taaa ttgct attgg & 1988-2007 & Lav51rev & aagaaagctgggtttgtcag & 8971-8952 \\
\hline Orf1-5-fw & acaa cagg cctc gtaa ggg & $2472-2490$ & Orf1-17rev & cggaa tctg tttcaa cacag & $9460-9441$ \\
\hline Lav73fw & aaaacttggcgctgcacgtc & $3102-3121$ & Orf1-18rev & ccagg tggtt gcaa tatcca & $9944-9925$ \\
\hline Orf1-6fw & ggtcc atta geca gcgect & $3451-3469$ & Orf1-19rev & aaaactccc gaag ttggtcg & $10385-10366$ \\
\hline Orf1-7fw & cttgag cagcg ccaa cattg & $3686-3705$ & Orf1-20rev & aggc ttgc tgtag tgggcat & $10762-10743$ \\
\hline Lav33fw & ggtgttggcacggcgagag & $4129-4147$ & Lav82rev & ttcaagctggaagtaggc & $11244-11225$ \\
\hline Orf1-8fw & catgg ctgtt gecca agtgt & $4538-4557$ & Orf1-21rev & tgatttt gctcc acag tgac & $11741-11722$ \\
\hline Orf1-9fw & ttgt gctt acgec tggecca & $4859-4878$ & Orf2arev & tcatr ccc tatt y tgc acca & $12558-12539$ \\
\hline Orf1-10fw & ggcgac tcct ataat cgtat & $5364-5383$ & Orf3rev & agaa aa gg cacgc ag aaa gca & $13184-13165$ \\
\hline Orf1-11fw & ccaa gcac ttcg cagg tccg & $5701-5720$ & Orf4rev & cattcagctcgcataicgtcaag & $13569-13547$ \\
\hline Orf1-12fw & ggctt ggctg ccgaaa tcgg & $6096-6115$ & Orf5Pesrev & ggg cgt ata tca tta tag gtg & $14100-14079$ \\
\hline Orf1-13fw & aatgaa gggag tctt gtcta & $6566-6586$ & Orf6rev & acccagc aa ctgg cacag & $14606-14589$ \\
\hline Lav92fw & gtgtatccctcggctaccac & $6891-6911$ & Orf7rev & tcg ccc taa ttg aa tagg tga & $14966-14946$ \\
\hline
\end{tabular}

Orf1-14fw

Orf1-15fw

Lav12fw

Orf1-16fw

Orf1-17fw

Lav51fw

Amp6fwint

Orf1-18fw

Orf1-19fw

Orf1-20fw

Orf2afw

LavORF2asegfw

Orf3fw

LavORF3seq1fw

Orf4fw

Orf5Pesfw

Orf6fw

Orfffw

Orf1-1-rev

Lavgsprev

Orf1-2-rev

Orf1-3-rev

ORF1-4-rev

Orf1-5-rev

Orf1-6-rev

Orf1-7-rev

Lav33rev

Orf1-8rev

Orf1-9rev

Amp3intrev2

Amp3intrev

Orf1-10rev catta gtcaa cttcaa ggtt

gga ccc tga gcgg catgaa

ccaagaactccatggcaggt

ggaaaaacaaattcaaggag

tccag cccatg ctggt ata

gtgtttgtttcactcacact

catcagaccatgtttgacat

aagge caggaa cacca gggt

cccagta tttgca ccttt gc

cggecgta cttgc aaccag

gts aca cck tat gatta cg

gtgttcgacaacgeccacacgc

agcc taca gta caa ca ccac

agcgttgagctcatcttccc

cgg ccc ait tcc atccigag

tga tca cat tcg gtt gct

tacc aa ctt tc ttc tggac

tgg cccc tgccc aic acg

gtcaa cacgt gggtgg ctcc

cgacttgacattctagtcca

agat gcca aacgg acgaa cc

gcag cctt cgga gcag acgc

cggtg aaca cgag acacc tg

gctg atgt tgtc ggatt ctg

ctggg aaca ggagg cgg tgt

ccccaacacttgtgacaacg

gt ccgag tccac tacaatc

agag ttgt gecac tgct gaaa

cagagaaggecggttattcct

gattccaatgagatcacca

gctc ggac taaaa cagc tgg gggttgg atg gagtc gagaa
7280-7299

7765-7783

8172-8191

8442-8461

8817-8835

9316-9335

9764-9783

10136-10155

10633-10652

11132-11150

11387-11406

11577-11598

12234-12253

12261-12280

12672-12691

13320-13337

13838-13856

14328-14345

701-681

900-881

1304-1285

1796-1777

2252-2233

2615-2596

3202-3182

3730-3711

3982-3963

4403-4385

4755-4735

5023-5003

5609-5591

5959-5940
Table 2 Oligonucleotide primers used in RT-PCR amplification and nucleotide sequencing of $07 \mathrm{V063}$ (Continued)

differences. Several motifs such as the transcription regulatory sequence (UUAACC) and CACCC stretches (involved in binding of host cell transcription factors) are conserved in 07V063 [18]. Table 3 gives an overview of all ORFs in the 07V063 genome and comparison with ORFs from prototype LV. Most variation with LV was

Table 3 Comparison of proteins from $07 \mathrm{~V} 63$ and prototype LV

\begin{tabular}{llllll}
\hline ORF & Protein & Size 07V63 & Size LV & \% identity & \% similarity \\
\hline la & Nsp1 & 385 & 385 & 85 & 91 \\
& Nsp2 & 833 & 861 & 81 & 85 \\
& Nsp3 & 447 & 447 & 93 & 96 \\
& Nsp4 & 203 & 203 & 92 & 96 \\
& Nsp5 & 170 & 170 & 96 & 97 \\
& Nsp6 & 16 & 16 & 100 & 100 \\
& Nsp7 & 269 & 269 & 96 & 97 \\
& Nsp8 & 45 & 45 & 100 & 100 \\
1b & Nsp9 & 645 & 645 & 96 & 98 \\
& Nsp10 & 442 & 442 & 94 & 97 \\
& Nsp11 & 224 & 224 & 95 & 97 \\
& Nsp12 & 152 & 152 & 93 & 96 \\
2a & GP2 & 249 & 249 & 93 & 94 \\
2b & E & 70 & 70 & 95 & 97 \\
3 & GP3 & 265 & 265 & 89 & 92 \\
4 & GP4 & 183 & 183 & 87 & 93 \\
5 & GP5 & 200 & 201 & 91 & 94 \\
6 & M & 173 & 173 & 93 & 94 \\
7 & N & 128 & 128 & 91 & 98 \\
\hline
\end{tabular}


noticed in Nsp1 (85\% identity/91\% similarity) and Nsp2 (81\% identity/85\% similarity). A major difference is a deletion of 28 aa in a variable region of Nsp2 (at positions 683-710). Similar deletions in this region are known e.g. EuroPRRS has a 17 aa deletion (Figure 2A; [18]). The deletion in NSP2 in 07V63 could be a unique marker for this strain.
Strain 07V063 showed 87 - 95\% aa identity with LV for the structural ORFs 2 - 7. We compared GP4 and GP5 proteins from 07V063 and LV since it has been shown that these proteins are the main target for neutralizing antibodies. Figure 2B shows an alignment of ORF4 proteins. Notably is the high variation in the region 50-70. It has been shown that a neutralizing

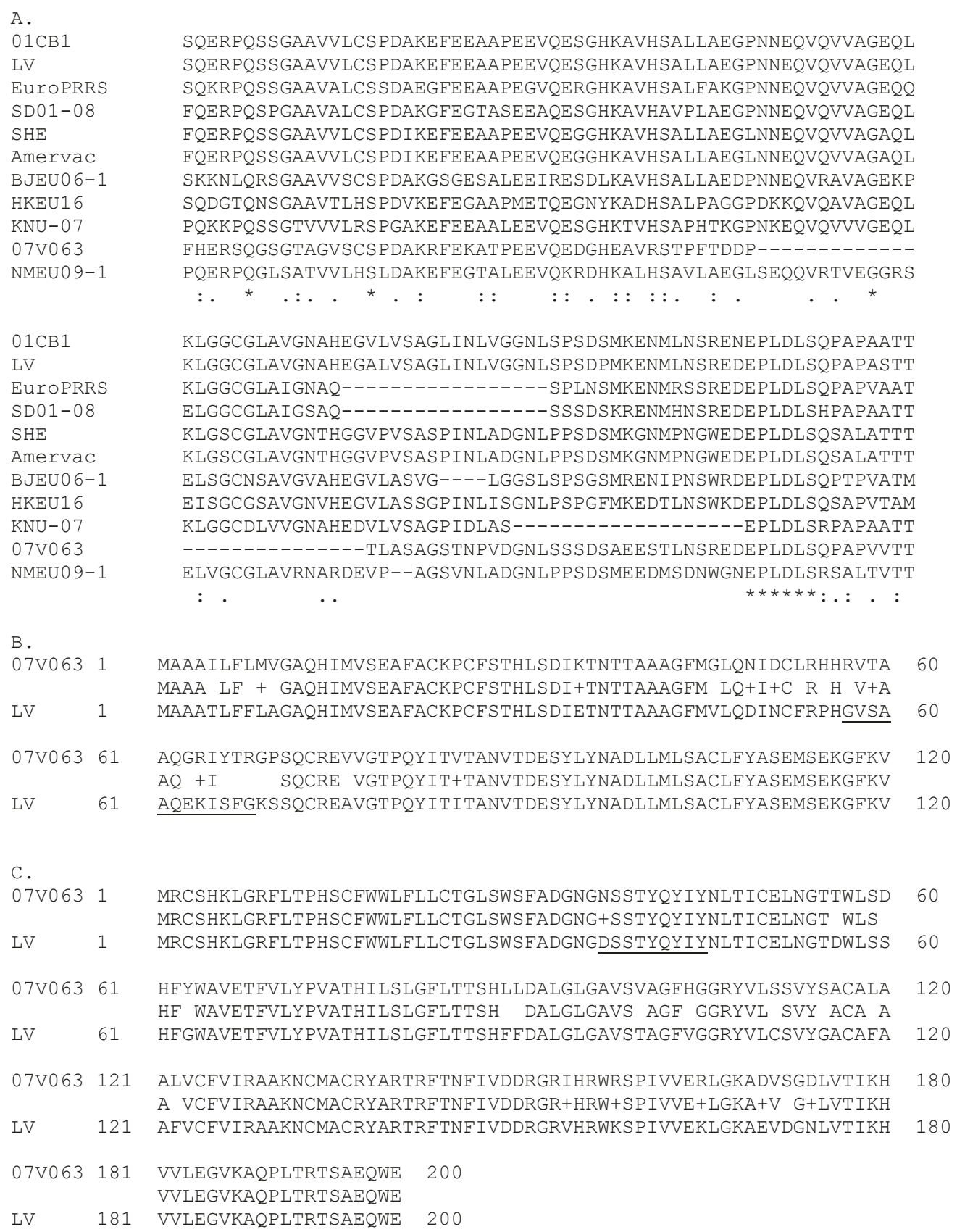

Figure 2 Alignment of Nsp2, ORF4 and ORF5 proteins from 07V063 with LV (ORF4 and ORF5) and a selection of genotype 1 strains (Nsp2). A. Alignment of Nsp2 proteins from genotype 1 strains. Only aa positions 636-755 (LV) are shown. The deletion in 07V063 is located at aa positions 683-710. B. Alignment of GP4 from 07V063 and LV (only the first 120 aa are shown). A neutralizing epitope in LV (57-68) is underlined. C. Alignment of GP5 from 07 V063 and LV. A neutralizing epitope in North American strains (37-45) is underlined. 
epitope is present in LV at positions 57-68 [19] and that this region is under antibody-mediated pressure in vitro and in vivo [20,21]. Pigs infected with 07V063 produce neutralizing antibodies against the ${ }^{57}$ RVTAAQGRIYTR ${ }^{68}$ epitope. However, these antibodies do not cross-protect against LV [22]. Similarly, antibodies against the same region in LV, do not cross-protect against 07V063. Interestingly, this lack of cross-neutralization is in agreement with the finding that strain 07V063 was able to replicate and cause disease on a farm where animals were vaccinated with the LV-like Porcilis ${ }^{\mathrm{TM}}$ vaccine.

GP5 has been described as the main target for virusneutralizing antibodies in North American PRRSV strains. A neutralizing epitope has been identified at positions 37-45 [23]. Figure 2C shows that 07V063 and LV have an identical sequence from 37-45 with the exception of an extra glycosylation site at position 37 in 07V063. It has been shown that several strains are glycosylated at this position but the significance of this glycosylation is not known. Other amino acid changes occur throughout the sequence and several of these positions have been described as variable [24]. No other differences in glycosylation pattern of the structural proteins between 07V063 and LV was observed.

\section{Phylogenetic relationship of 07V063}

Since ORF5 is frequently used as a marker for the study of genetic relationships [8], we constructed phylogenetic trees using ORF5 sequences from a selection of genotype 1 strains (Table 4). In addition genotype 1 strains for which the full length sequence was available in Genbank were included. VR-2332 (genotype 2) was used as out-group.

Figure 3A shows a phylogenetic tree of ORF5 DNA sequences based on the Neighbour Joining (NJ) method. Several clusters are evident and supported by high bootstrap values. It can be concluded that 07V063 clusters within the pan-European subtype 1 [8]. Within subtype 1 , a cluster with LV- and Olot/91-like strains can be distinguished. Although both LV and Olot/91 belong to the earliest PRRSV isolates, still LV and Olot/91-like strains such as SD01-08 are circulating. Strain 07V063 is genetically different from LV- and Olot/91- like strains. Apparently 07V063 clusters together with isolates from different geographical locations e.g. isolates from Spain (16/2000), Denmark (361-4), China (BJEU06-1) and South-Korea (IV3140) although this clustering is not supported by high bootstrap values. A similar tree topology was obtained using ORF5 protein sequences (data not shown). The sub-clustering of type 1 is complex and cannot always be explained by geographic isolation of the strains [8]. The sequence of 07V63 adds to the increase of genetic diversity of type 1 strains and is an example of continuous genetic drift within PRRSV [24].
Table 4 Overview of strains used for phylogenetic analysis

\begin{tabular}{|c|c|c|c|}
\hline Strain & Genotype & $\begin{array}{l}\text { Genbank } \\
\text { Accession ORF5 }\end{array}$ & $\begin{array}{l}\text { Genbank Accession } \\
\text { ORF1a (nsp2) }\end{array}$ \\
\hline VR-2332 & 2 & U87392 & U87392 \\
\hline Lelystad & 1 (subtype 1) & M96262 & M96262 \\
\hline EuroPRRS & 1 & AY366525 & AY366525 \\
\hline 01-CB1 & 1 (subtype 1) & DQ864705 & DQ864705 \\
\hline Amervac & 1 (subtype 1) & GU067771 & GU067771 \\
\hline HKEU16 & 1 (subtype 1) & EU076704 & EU076704 \\
\hline KNU-07 & 1 (subtype 1) & FJ349261 & FJ349261 \\
\hline SHE & 1 (subtype 1) & GQ461593 & GQ461593 \\
\hline SD01-08 & 1 (subtype 1) & DQ489311 & DQ489311 \\
\hline BJEU06-1 & 1 (subtype 1) & GU047344 & GU047344 \\
\hline $\begin{array}{l}\text { NMEU09- } \\
1\end{array}$ & 1 (subtype 1) & GU047345 & GU047345 \\
\hline 07V063 & 1 (subtype 1) & GU737264 & GU737264 \\
\hline PyrsVac & 1 (subtype 1) & DQ324681 & ND \\
\hline Porcilis & 1 (subtype 1) & AAW78901 & ND \\
\hline Olot/91 & 1 (subtype 1) & X92942 & ND \\
\hline Yuz-34 & 1 (subtype 3) & DQ324692 & ND \\
\hline Bel-42 & 1 (subtype 3) & DQ324669 & ND \\
\hline Obu-1 & 1 (subtype 3) & DQ324671 & ND \\
\hline Soz-6 & 1 (subtype 3) & DQ324686 & ND \\
\hline Dzi-62 & 1 (subtype 1) & DQ324675 & ND \\
\hline Cresa11 & 1 (subtype 1) & DQ009626 & ND \\
\hline IV3140 & 1 (subtype 1) & DQ355821 & ND \\
\hline 28639/98 & 1 (subtype 1) & AY035912 & ND \\
\hline $361-4$ & 1 (subtype 1) & AY035915 & ND \\
\hline Sno-4 & 2 (subtype 2) & DQ324683 & ND \\
\hline Sid & 2 (subtype 2) & DQ324682 & ND \\
\hline Aus & 2 (subtype 2) & DQ324667 & ND \\
\hline Okt-35 & 1 & DQ324677 & ND \\
\hline $16 / 2000$ & 1 & DQ345743 & $N D$ \\
\hline SD02-11 & 1 (subtype 1) & AY395078 & AY383634 \\
\hline SD01-07 & 1 (subtype 1) & AY395079 & AY383632 \\
\hline SD03-12 & 1 (subtype 1) & AY395074 & AY383635 \\
\hline SD03-15 & 1 (subtype 1) & AY395076 & AY383636 \\
\hline $\mid t-22$ & 1 (subtype 1) & AY739978 & $N D$ \\
\hline It-39 & 1 (subtype 1) & AY739995 & ND \\
\hline It-44 & 1 (subtype 1) & AY740000 & ND \\
\hline $\mid t-35$ & 1 (subtype 1) & AY739991 & ND \\
\hline $\mid t-13$ & 1 (subtype 1) & AY739969 & ND \\
\hline Lena & 1 (subtype 3 ) & EU909691 & ND \\
\hline
\end{tabular}

The type of the strains is according to Stadejek et al (2008). ND = no data. VR2332 is genotype 2 . Eleven genotype 1 isolates for which full length sequences were obtained are listed first.

A recent PRRSV study in Spain [25] demonstrated that Spanish isolates from different years show continuous evolution and increase in heterogeneity and that different genotypes and variants within the genotypes cocirculate. 


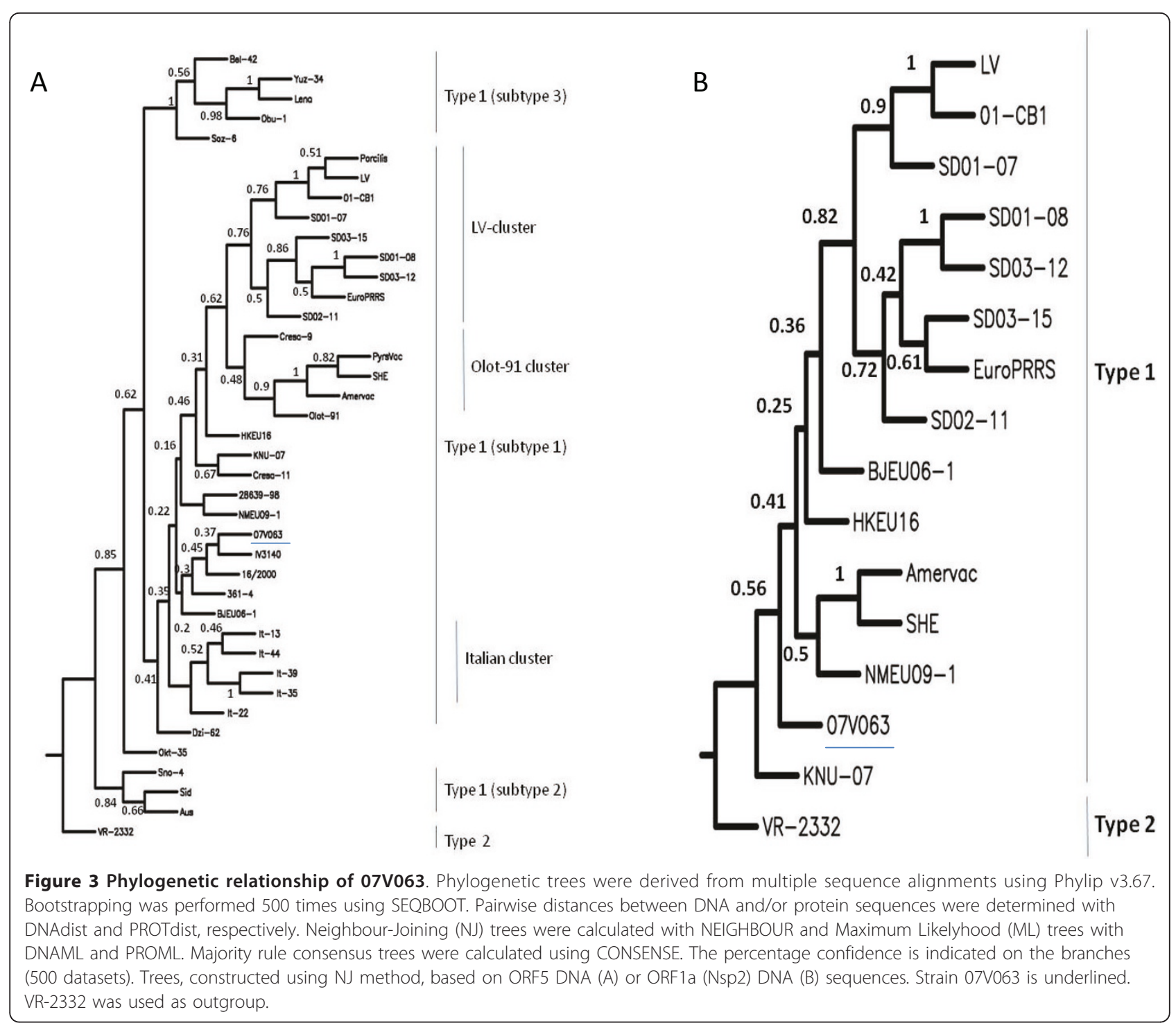

Also, phylogenetic trees using Nsp2 were constructed (Figure 3B). Sequences from all known full length genotype 1 strains (Table 4) were included. Essentially, the same topology can be observed as for ORF5. A cluster of LV-like strains is evident and supported by high bootstrap values. As was already observed from the ORF5 phylogenetic tree, Amervac and SHE are very closely related as is the case for strains $01-\mathrm{CB} 1$ and LV. 07V063 clusters apart from LV and is genetically distinct from the LV prototype.

\section{Conclusions}

By using a simple random PCR cloning approach we obtained PRRSV sequence data from a recent European PRRSV isolate of unknown genetic background. This approach can be used to obtain partial genome sequences from for instance East-European type strains (for which until present, no full length genomes are available) and to get a better knowledge of the increasing PRRSV variability. We also showed that the isolate sequenced in this study is genetically different from prototype LV.

\section{List of abbreviations}

PRRSV: porcine reproductive and respiratory syndrome virus; RT-PCR: reverse transcriptase polymerase chain reaction.

\section{Acknowledgements}

This work was supported by the Industrial Research Fund (IOF) of Ghent University. The authors would like to thank Ine Vanherpe for technical assistance and Merijn Vanhee for critical reading of the manuscript.

\section{Author details}

${ }^{1}$ Department of Health Care and Biotechnology, KATHO Catholic University College of South-West Flanders, Wilgenstraat 32, 8800 Roeselare, Belgium. ${ }^{2}$ Department Virology, Parasitology and Immunology, Faculty of Veterinary Medicine, Ghent University, Salisburylaan 133, 9820 Merelbeke, Belgium. 
${ }^{3}$ ProVaxs, Faculty of Medicine and Health, Ghent University, De Pintelaan 185 - 3K3, 9000 Gent, Belgium.

\section{Authors' contributions}

JVD carried out the molecular characterization and drafting of the manuscript. MG isolated the virus and performed IPMA analysis. HJN participated in coordination and supervision of this work. PLD participated in the design and coordination of the study and drafting of the manuscript. All authors read and approved the manuscript.

\section{Competing interests}

The authors declare that they have no competing interests.

Received: 26 January 2011 Accepted: 10 April 2011

Published: 10 April 2011

\section{References}

1. Wensvoort G, de Kluyver EP, Pol JM, Wagenaar F, Moormann RJ, Hulst MM, Bloemraad R, den Besten A, Zetstra T, Terpstra C: Lelystad virus, the cause of porcine epidemic abortion and respiratory syndrome: a review of mystery swine disease research at Lelystad. Vet Microbiol 1992, 33 185-193.

2. Cano JP, Dee SA, Murtaugh MP, Trincado CA, Pijoan CB: Effect of vaccination with a modified-live porcine reproductive and respiratory syndrome virus vaccine on dynamics of homologous viral infection in pigs. Am J Vet Res 2007, 68: 565-571.

3. Cano JP, Dee SA, Murtaugh MP, Pijoan C: Impact of a modified-live porcine reproductive and respiratory syndrome virus vaccine intervention on a population of pigs infected with a heterologous isolate. Vaccine 2007, 25: 4382-4391.

4. Labarque G, Van Reeth K, Nauwynck H, Drexler C, Van Gucht S, Pensaert M: Impact of genetic diversity of European-type porcine reproductive and respiratory syndrome virus strains on vaccine efficacy. Vaccine 2004, 22: 4183-4190.

5. Scortti M, Prieto C, Alvarez E, Simarro I, Castro JM: Failure of an inactivated vaccine against porcine reproductive and respiratory syndrome to protect gilts against a heterologous challenge with PRRSV. Vet Rec 2007, 161: 809-813.

6. Prieto C, Alvarez E, Martinez-Lobo FJ, Simarro I, Castro JM: Similarity of European porcine reproductive and respiratory virus strains to vaccine strain is not necessarily predictive of the degree of protective immunity conferred. Vet J 2008, 175: 356-363

7. Stadejek T, Oleksiewicz MB, Potapchuk D, Podgorska K: Porcine reproductive and respiratory syndrome virus strains of exceptional diversity in eastern Europe support the definition of new genetic subtypes. J Gen Virol 2006, 87: 1835-1841.

8. Stadejek T, Oleksiewicz MB, Scherbakov AV, Timina AM, Krabbe JS, Chabros K, Potapchuk D: Definition of subtypes in the European genotype of porcine reproductive and respiratory syndrome virus: nucleocapsid characteristics and geographical distribution in Europe. Arch Virol 2008, 153: 1479-1488.

9. Balka G, Hornyak A, Balint A, Kiss I, Kecskemeti S, Bakonyi T, Rusvai M: Genetic diversity of porcine reproductive and respiratory syndrome virus strains circulating in Hungarian swine herds. Vet Microbiol 2008, 127: $128-135$

10. Meng XJ: Heterogeneity of porcine reproductive and respiratory syndrome virus: implications for current vaccine efficacy and future vaccine development. Vet Microbiol 2000, 74: 309-329.

11. Yoon KJ, Zimmerman JJ, MCGinley MJ, Landgraf J, Frey ML, Hill HT, Platt KB: Failure to consider the antigenic diversity of porcine respiratory and reproductive syndrome (PRRS) virus isolates may lead to misdiagnosis. J Vet Diagn Invest 1995, 7: 386-387.

12. Indik S, Schmoll F, Sipos W, Klein D: Genetic variability of PRRS virus in Austria: consequences for molecular diagnostics and quantification. Vet Microbiol 2005, 107: 171-178.

13. Ambrose HE, Clewley JP: Virus discovery by sequence-independent genome amplification. Rev Med Virol 2006, 16: 365-383.

14. Allander T, Tammi MT, Eriksson M, Bjerkner A, Tiveljung-Lindell A, Andersson B: Cloning of a human parvovirus by molecular screening of respiratory tract samples. Proc Natl Acad Sci USA 2005, 102: 12891-12896.
15. Wieczorek-Krohmer M, Weiland F, Conzelmann K, Kohl D, Visser N, van Woensel $P$, Thiel HJ, Weiland E: Porcine reproductive and respiratory syndrome virus (PRRSV): monoclonal antibodies detect common epitopes on two viral proteins of European and U.S. isolates. Vet Microbiol 1996, 51: 257-266.

16. Delputte PL, Nauwynck HJ: Porcine arterivirus infection of alveolar macrophages is mediated by sialic acid on the virus. J Virol 2004, 78 : 8094-8101.

17. Karniychuk UU, Geldhof M, Vanhee M, Van Doorsselaere J, Saveleva TA, Nauwynck HJ: Pathogenesis and antigenic characterization of a new East European subtype 3 porcine reproductive and respiratory syndrome virus isolate. BMC Vet Research 2010, 6: 30.

18. Ropp SL, Mahlum Wees CE, Fang Y, Nelson EA, Rossow KD, Bien M, Arndt B, Preszler S, Steen P, Christopher-Hennings J, Collins JE, Benfield DA, Faaberg KS: Characterization of emerging European-like porcine reproductive and respiratory syndrome virus isolates in the United States. J Virol 2004, 78: 3684-3703.

19. Meulenberg JJ, van Nieuwstadt AP, van Essen-Zandbergen A, Langeveld JP: Posttranslational processing and identification of a neutralization domain of the GP4 protein encoded by ORF4 of the Lelystad Virus. $J$ Virol 1997, 71: 6061-6070

20. Costers S, Lefebvre DJ, Vanhee M, Geldhof M, Van Doorsselaere J, Delputte PL, Nauwynck HJ: GP4 of porcine reproductive and respiratory syndrome virus contains a neutralizing epitope that is susceptible to immuno-selection in vitro. Arch Virol 2010, 155: 371-378.

21. Costers S, Vanhee M, Van Breedam W, Van Doorsselaere J, Geldhof M, Nauwynck H: GP4-specific neutralizing antibodies might be a driving force in PRRSV evolution. Virus Res 2010, 154: 104-113.

22. Vanhee M, Costers S, Van Breedam W, Geldhof MF, Van Doorsselaere J, Nauwynck HJ: A variable region in GP4 of European-type porcine reproductive and respiratory syndrome virus induces neutralizing antibodies against homologous but not heterologous virus strains. Viral Immunol 2010, 23: 1-11.

23. Ostrowski M, Galeote JA, Jar AM, Platt KB, Osorio FA, Lopez OJ: Identification of neutralizing and nonneutralizing epitopes in the porcine reproductive and respiratory syndrome virus GP5 ectodomain. J Virol 2002, 76: 4241-4250.

24. Pesh S, Meyer C, Ohlinger VF: New insights into the genetic diversity of European porcine reproductive and respiratory syndrome virus (PRRSV). Vet Microbiol 2005, 107: 31-48.

25. Prieto C, Vazquez A, Nunez Jl, Alvarez E, Simarro I, Castro JM: Influence of time on the genetic heterogeneity of Spanish porcine reproductive and respiratory syndrome virus isolates. Virol J 2009, 180: 363-370.

doi:10.1186/1743-422X-8-160

Cite this article as: Van Doorsselaere et al: Characterization of a circulating PRRSV strain by means of random PCR cloning and full genome sequencing. Virology Journal 2011 8:160

\section{Submit your next manuscript to BioMed Central and take full advantage of:}

- Convenient online submission

- Thorough peer review

- No space constraints or color figure charges

- Immediate publication on acceptance

- Inclusion in PubMed, CAS, Scopus and Google Scholar

- Research which is freely available for redistribution 